\title{
ANALISIS KECACATAN PRODUK FILLET SKIN ON RED MULLET DENGAN THE BASIC SEVEN TOOLS OF QUALITY DAN USULAN PERBAIKANNYA MENGGUNAKAN METODE FMEA (FAILURE MODES AND EFFECT ANALYSIS) PADA PT. HOLI MINA JAYA
}

\section{Andi Trias Aryanto \\ Tuwanku Aria Auliandri \\ Departemen Manajemen Fakultas Ekonomi dan Bisnis Universitas Airlangga}

\begin{abstract}
Increasingly fierce competition make quality becomes a more value in the eyes of consumers. Keeping quality of being a need for companies to be able to stay in business. PT. Holi Mina Jaya is an Indonesian company that is engaged in marine fish processing. One of the flagship products offered are Fillet Skin On Red Mullet. The purpose of this study was to identify factors disability that occurs in the product Red Mullet Fillet Skin On analysis of the seven basic tools of quality and propose improvements to the failure modes and effects analysis (FMEA). The study focused on the stages of production that have a direct impact on the finished products includes receiving, filleting, and washing.
\end{abstract}

This study uses five of the seven basic quality tools, which flow charts, check sheets, histograms, cause and effect diagram and Pareto charts to identify defects. For quality improvement proposals using FMEA method by finding the value of the RPN (Risk Priority Number), have described the RPN value calculation by multiplying the value of Severity, Occurrence and Detection. Highest cause of any kind of disability, like any form of meat are less scrupulous employees, and skilled with the value of RPN 120, not fresh fish product defects are less rigorous sorting process HR RPN value by 54, and the last meat is not clean of thorns is less scrupulous employees with RPN at 36.

Kayword: Fillet Skin On Red Mullet, Product Defect, The Basic seven Tools of Quality, Failure Modes and Effect Analysis

\section{PENDAHULUAN}

Tidak diragukan lagi persaingan di dunia bisnis semakin ketat. Apalagi dengan adanya globalisasi, persaingan bukan hanya ditingkat regional saja melainkan sudah memasuki ranah internasional. Untuk itu perusahaan dituntut agar dapat menghasilkan barang secara efektif dan efisien. Dengan begitu dapat menciptakan keunggulan kompetitif yang bisa digunakan untuk bersaing dengan perusahaan lain. Banyak manfaat dari efektifitas dan efisiensi produksi mencakup pengurangan biaya, peningkatan produktivitas, pertumbuhan pangsa pasar, retensi pelanggan, pengurangan waktu siklus, pengurangan defect (cacat), dan pengembangan produk/jasa (Pande, et al., 2003). 


\section{Andi Trias Aryanto \\ Tuwanku Aria Auliandri}

Salah satu sektor bisnis yang mengalami tren pertembuhan naik adalah sektro perikanan. Sektor perikanan adalah salah satu sektor yang sangat penting karena memiliki potensi kontribusi yang besar terhadap produk domestik bruto (PDB). Kepala Sekretariat Dewan Kelautan Indonesia, Asrul mengatakan, kontribusi perikanan terhadap total produk domestik bruto (PDB) nasional sebesar 2,75\%, lalu pertambangan minyak dan gas bumi mencapai $6,24 \%$, pengilangan minyak bumi $2,46 \%$, gas alam cair (LNG) $1,56 \%$, angkutan laut berkontribusi sebesar $0,35 \%$, angkutan sungai dan penyeberangan sebesar $0,12 \%$ (www.ipotnews.com). Namun seiring dengan adanya pasar bebas ASEAN atau Masyarakat Ekonomi ASEAN (MEA) yang belaku pada akhir tahun 2015 membuat persaingan semakin ketat itu berlaku pula di sektor perikanan. Melihat kondisi tersebut, perusahaan yang ada di sektor perikanan harus dapat mempertahankan bisnisnya melalui strategi yang tepat. Salah satu strategi bisnis yang dapat dilakukan adalah dengan meningkatkan kualitas produk.

PT. Holi Mina Jaya merupakan perusahaan yang bergerak dalam bidang pengolahan makanan laut setengah jadi. Hasil produksinya meliputi seafood beku dan surimi beku. Seafood beku terdiri dari ikan, udang, dan cephalopoda (hewan dengan kepala berkaki seperti gurita dan cumi-cumi), sedangkan surimi beku terdiri dari itoyori, eso, kintokida, black itoyori, himeji, kurosagi, dan guchi. Surimi merupakan produk setengah jadi berupa protein ikan yang disimpan beku. Produk ini awalnya berkembang dan populer di Jepang. Dua jenis surimi yang biasa diproduksi adalah mu-en surimi yaitu surimi yang dibuat tanpa penambahan garam dan ka-en surimi yaitu surimi yang dibuat dengan penambahan garam.

Pada penelitian ini yang akan diteliti adalah tahapan proses pada produk ikan beku yaitu fillet skin on red mullet, dimana produk tersebut merupakan kategori seafood beku. Alasan penulis menggunakan fillet skin on red mullet sebagai objek penelitian adalah karena produk tersebut merupakan salah satu produk unggulan dari perusahaan dengan produksi mencapai satu ton ikan red mullet perharinya atau 450 box kemasan. Sehingga perusahaan perlu melakukan kontrol kualitas produksi yang baik dengan pengawasan langsung maupun dengan tools pengendalian kualitas.

Digunakan cause and effect diagram dan diagram pareto untuk mengidentifikasi penyebab kegagalan. Cause and effect diagram digunakan dalam memudahkan mengidentifikasi penyebab kegagalan pada proses produksi (Foster, 2007:310). Sedangkan diagram pareto digunakan untuk mengidentifikasi dan memprioritaskan masalah yang akan diselesaikan terlebih dahulu (Foster, 2007:312). Dari hasil analisis akan diberikan usulan perbaiakan menggunakan metode Failur Models and Effect Analysis (FMEA). FMEA adalah teknik analisis yang mengkombinasikan teknologi dengan pengalaman seseorang dalam 


\section{Jurnal Manajemen Teori dan Terapan \\ Tahun 8. No. 1, April 2015}

mengidentifikasi bentuk kegagalan yang akan datang dari suatu produk atau proses dan merencanakan untuk meghilangkan setiap bentuk kegagalan tersebut (Besterfield et al., 2003:377). FMEA dalam penelitian ini memberikan bobot penilaian berupa nilai Risk Priority Number (RPN) ata penyebab kegagalan produk sehingga dapat diketahui permasalahan yang harus diselesaikan terlebih dahulu.

Rumusan masalah dalam penelitian ini adalah sebagai berikut:

1. Bagaimana identifikasi proses produksi yang menyebabkan kecacatan produk fillet skin on red mullet?

2. Bagaimana usulan perbaikan kualitas produk fillet skin on red mullet berdasarkan tindakan rekomendasi dari metode FMEA?

Tujuan penelitian ini adalah sebagai berikut:

1. Mengetahui pengaruh entrepreneurial orientation terhadap firm growth pada UMKM meubel yang ada di Kabupaten Tuban.

2. Mengetahui pengaruh business organizational characteristics memperkuat pengaruh entrepreneurial orientation terhadap firm growth pada UMKM meubel yang ada di Kabupaten Tuban.

\section{LANDASAN TEORI}

Definisi Kualitas

Kualitas mempunyai pengaruh yang besar terhadap perusahaan secara keseluruhan, meliputi pemasok hingga ke pelanggan dan dari desain produk sampai pemeliharaannya. Akan tetapi hal yang lebih penting adalah membangun sebuah perusahaan yang dapat mencapai kualitas yang ditentukan dan mempengaruhi perusahaan secara keseluruhan. Kualitas mempunyai banyak pengertian menurut para ahli, seperti yang dikatakan Juran (1989: 15) kualitas sebagai kesesuaian untuk digunakan dan mencakup keistimewaan produk yang memenuhi kebutuhan konsumen serta bebas dari pemborosan.

The Basic Seven Tools of Quality

Tujuh alat pengendali kualitas pertama kali diperkenalkan oleh Ishikawa pada tahun 1960an. Tujuh alat pengendali kualitas adalah sebuah metode yang digunakan untuk mendeskripsikan masalah-masalah yang terdapat pada suatu sistem kerja dan kemudian mencari penyebab dari terjadinya masalah tersebut (Heizer dan Render, 2006). Sven tools dapat di bagi menjadi bebrapa bagian berdasarkan tahapannya. Pada tahap pertama merupakan tahap pemrosesan data dengan menggunakan flow chart, dan check sheet. Kemudian tahap selanjutnya adalah analisis dengan menggunkan histogram, scatter plot, dan control chart. Selanjutnya adalah tahap identifkasi akar penyebab terjadinya permasalahan yaitu dengan menggunakan cause adn effect diagram. Tahapan terakhir pencarian penyebab masalah yang paling dominan menggunakan doagram praeto (Foster, 2007:297).

Flow chart 


\section{Andi Trias Aryanto \\ Tuwanku Aria Auliandri}

Pada tahap awal pengendalian kualitas diperlukan tool yang menggambarkan proses dari awal sampai akhir yang dinamakan flow chart. Process map atau flow chart adalah mengidentifkasi urutan kegiatan atau aliran bahan dan informasi dalam suatu proses atau sistem (Evans dan Lindsay, 2008:650). Flow chart membantu orang yang terlibat dalam proses memahaminya jauh lebih baik dan lebih obyektif dengan memberikan gambaran tentang langkah-langkah yang diperlukan untuk menyelesaikan tugas.

Check sheets

Check sheets adalah sebuah formulir yang digunakan untuk mempermudah pencatatan data yang sudah dikumpulkan sebelumnya. Menurut Evans dan Lindsay (2008:656) check sheets adalah jenis khusus dari bentuk pengumpulan data yang hasilnya dapat diartikan pada formulir langsung tanpa pengolahan tambahan. Sedangkan menurut Heizer dan Render (2009:316) check sheets adalah suatu formulir yang dirancang untuk mencatat data.

\section{Histogram}

Histogram adalah tabel yang memberikan petunjuk tentang karakteristik populasi induk dari sampel yang diambil, dan membentuk pola yang tidak bisa dilihat dari tabel angka biasa (Evans dan Lindsay. 2008:657). Histogram menunjukan cakupan nilai dari sebuah perhitungan dan frekuensi dari setiap nilai yang muncul.

\section{Scatter plot}

Scatter plot adalah komponen grafik yang ada dalam analisis regresi (Evans dan Lindsay. 2008:662). Scatter plot menghubungkan dua faktor yang bervariasi pada sebuah kontinum. Scatter plot dapat menjadi alat yang sangat baik untuk menguji hubungan antara penyebab yang diduga menjadi penyebab masalah. Scatter plot juga dapat menunjukakan hubungan kausal yang penting antara satu faktor dan faktor laimnya.

\section{Control chart}

Control chart merupakan cara ideal untuk memonitor kinerja proses saat ini. Menurut Heizer dan Render (2009:322) control chart adalah representasi grafis dari data proses yang sejalan dengan waktu, dengan batas-batas kendali yang telah ditentukan. Control chart menunjukkan kinerja dan variasi proses atau kualitas, dan indikator produktivitas dari waktu ke waktu secara grafis yang mudah untuk dipahami dan ditafsirkan (Evans dan Lindsay. 2008:654). Selain itu control chart juga mengidentifikasikan proses perubahan dan tren dari waktu ke waktu dan menunjukan efek dari tindakan korektif.

Cause and effect diagram

Cause and effect diagram atau diagram Ishikawa atau juga sering disebut fishbone diagram adalah sebuah teknik skematik yang digunakan untuk mengetahui letak-letak masalah kualitas yang mungkin terjadi (Heizer dan Render. 2009:318). Metode ini pertama 
kali dikenalkan oleh Dr. Kaoru Ishikawa pada tahun 1953. Cause and effect diagram merupakan alat yang bagus untuk memisahan masalah ke level yang lebih rendah sehingga dapat membantu untuk memecahakan masalah.

Diagram pareto

Diagram pareto dibuat berdasakan karya Vilfredo Pareto, seorang pakar ekonomi berkebangsaan Italia di abad ke 19. Dan dipopulerkan oleh Joseph M. Juran memopulerkan pekerjaan Pareto dengan menyatakan $80 \%$ permasalahan perusahaan merupakan hasil dari penyebab yang $20 \%$ saja. Diagram pareto adalah sebuah metode untuk mengelola kesalahan, masalah, atau cacat guna membantu memusatkan perhatian untuk upaya penyelesaian masalahnya (Heizer dan Render. 2009:319).

Failur Model and Effect Analysis

Menurut Pande, et al. (2002:402) Failur Model and Effect Analysis (FMEA) adalah sekumpulan petunjuk, sebuah proses, dan form untuk mengidentifikasi dan mendahulukan masalah-masalah potensial (kecacatan). Sedangkan FMEA menurut Besterfield (2003:377) merupakan suatu teknik analisis yang menggabungkan teknologi dan keahlian seseorang untuk mengidentifikasi mode kecacatan produk atau yang dapat diperkirakan dan membuat perencanaan untuk menghilangkannya. Hasil dari proses FMEA secara rinci menjelaskan tentang bagaimana kecacatan mempengaruhi kinerja sistem dan keselamatan kerja.

Proses FMEA

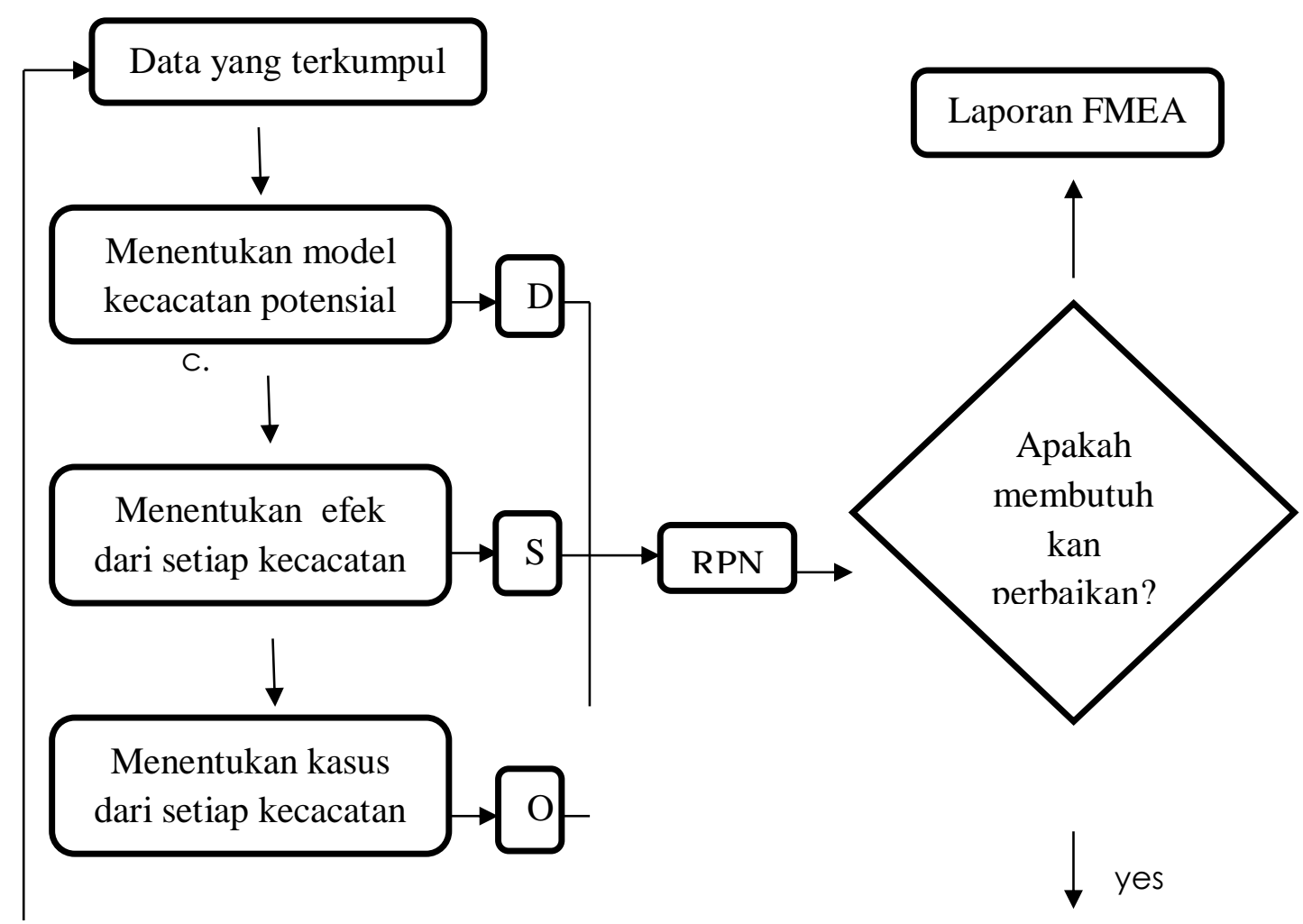




\section{Andi Trias Aryanto \\ Tuwanku Aria Auliandri}

Tindakan perbaikan

data modifikasi

\section{METODE PENELITIAN}

Pendekatan yang digunakan pada penelitian ini adalah pendekatan kualitatif dengan metod stud deskriptif. Pendekatan kualitatif menurut Wirartha (2006:134) adalah penelitian yang dilakukan pada kondisi obyek yang alami, di mana peneliti merupakan instrumen kunci, dan teknik pengumpulan data dilakukan secara gabungan. Metode studi deskriptif adalah metode yang dilakukan untuk menganalisis satu atau lebih variabel tanpa membuat perbandingan atau menghubungkan antara variabel yang satu dengan variabel yang lain (Suliyanto. 2006:9).

Batasan Penelitian

Penelitian dilakukan pada produk fillet skin on red mullet. Produk ini dipilih karena merupakan salah satu produk unggulan dari PT. Holi Mina Jaya. Penelitian hanya dilakukian pada bagian receiving, filleting, dan washing pada proses produksi. Karena pada bagian tersebut rawan terjadinya kececatan produk. Evaluasi yang dilakukan menggunakan data kecacatan produk pada tahun 2014, karena periode tersebut merupakan periode terdekat dengan penelitian. Evaluasi dilakukan dengan menggunakan the basic seven tools of quality, dari tujuh alat yang ada digunakan lima alat kualitas. Dan terakhir diagram paretoakan digunakan untuk mengetahui penyebab utama kecacatan, sehingga dapat diselesaikan terlebih dahulu atau diprioritsakan. Dari hasil analisis yang dilakukan menggunakan enam dari tujuh alat pengendali kualitas, akan dijadikan untuk usulan perbaikan dengan metode FMEA.

Jenis dan sumber data

Data yang digunakan dalam penelitian ini adalah sebagai berikut:

1. Data Primer

Data primer adalah data yang dikumpulkan sendiri oleh peneliti langsung dari sumber pertama, baik berupa lisan ataupun tulisan. Data tersebut meliputi tahapan proses produksi, bentuk-bentuk kecacatan produk, penyebab kecacatan produk, kontrol yang telah dilakukan oleh perusahaan, dan tindakan untuk mengatasi kecacatan yang terjadi.

2. Data Sekunder

Data sekunder merupakan data yang diterbitkan atau digunakan oleh organisasi yang bukan pengolahnya. Data sekunder dalam penelitian ini adalah sejarah 
perusahaan, struktur organisasi, visi dan misi perusahaan, data jumlah produksi tahun 2014, dan data kecacatan produk tahun 2014.

Prosedur Pengumpulan Data

Dalam penelitian ini prosedur pengumpulan data yang dilakukan adalah sebagai berikut:

1. Survey Pendahuluan

Survey pendahuluan dilakukan guna memperoleh gambaran dari permasalahan yang akan diteliti, sehingga dapat mengetahui langkah-langkah yang akan dilakukan dalam penelitaian tersebut. Dari hasil survey pendauluan tersebut penulis kemudaian dapat mengetahui gambaran proses produksi perusahaan, dan tahapan proses produksi yang paling banyak menghasilkan kecacatan produk. Oleh sebab itu, peneliti dapat mengetahui masalah yang akan diteliti. Selain itu, survey pendahuluan juga berguna untuk menemukan penelitian sebelumnya sebagai dasar perbandingan hasil yang akan diperoleh dalam penelitian ini.

2. Studi Literatur

Studi literatur merupakan pengumpulan data yang berasal dari eksternal organisasi yang diteliti, dan mempunyai relevasi dengan penelitian. Tinjauan pustaka ini sangat berguna untuk mengumpulkan data-data sekunder yang berkaitan dengan teori yang mendasari penelitian ini.

3. Studi Lapangan

Studi lapangan dilakukan dengan cara mengunjungi perusahaan yang merupakan obyek penelitian. Dan mengumpulkan data-data yang diperlukan dalam penelitian dengan cara sebagai berikut:

a. Observasi, yaitu pengamatan atau penyelidikan yang dilakukan secara langsung untuk mendapatkan keterangan mengenai proses produksi. Observasi dilakukan di PT. Holi Mina Jaya pada proses produksi fillet skin on red mullet.

b. Wawancara, yaitu teknik pengumpulan data melalui tanya jawab dengan pihak internal perusahaan yang memiliki kapasitas dan bertanggung jawab atas proses produksi. Wawancara dilakukan dengan pihak internal dari perusahaan, yaitu Manajer Produksi dan Supervisor dari PT. Holi Mina Jaya, untuk memperoleh data-data penelitian yang dibutuhkan.

Teknik Analisis

Teknik analisi yang digunakan dalam penelitian ini antara lain:

a. Analisis menggunakan the basic seven tools of quality:

1. Membuat alur proses produksi fillet skin on red mullet dengan flowchart. 


\section{Andi Trias Aryanto \\ Tuwanku Aria Auliandri}

2. Mencatat jumlah frekuensi fillet skin on red mullet yang mengalami kecacatan produk menggunakan check sheet pada tahap receiving, filleting, dan washing.

3. Membuat histogram untuk mengetahui jumlah kecacatan produk yang terjadi tiap bulannya pada tahun 2014.

4. Menentukan penyebab kecacatan produk yang paling dominan berdasarkan kontribusi masing-masing penyebab menggunakan diagram pareto.

5. Dengan menggunakan cause and effect diagram untuk mengetahui akar dari penyebab kecacatan produk fillet skin on red mullet. Akar permaslahan tersebut diklasifikasikan dalam 5 kategori, yaitu material (bahan baku), tools (peralatan), method (metode), man (orang), dan temperature (kondisi suhu).

b. Tahapan analisis dengan metode FMEA, adalah sebagai berikut:

1. Menentukan tahapan produksi yang akan diidentifikasi, yaitu tahap receiving, filleting, dan washing.

2. Mengidentifikasi bentuk kecacatan produk yang muncul pada tahap receiving, filleting, dan washing.

3. Mencatat akibat yang timbul dari permasalahan yang terjadi.

4. Mengidentifikasi penyebab yang berkontribusi menimbulkan kecacatan produk pada setiap tahapan.

5. Mencatat upaya pengendalian yang dilakukan oleh persusahaan untuk mendeteksi kecacatan produk.

6. Mentukan nilai dari severity, occurrence, dan detection berdasarkan skala dari 1 sampai 10 untuk masing-masih faktor.

7. Menghitung risk priority number dari hasil perkalian nilai severity, occurrence, dan detection.

8. Dengan melihat hasil RPN memberikan usulan perbaikan yang sesuai dengan permasalahan yang terjadi, sehingga dapat meminimalkan jumlah kecacatan produk. 
HASIL DAN PEMBAHASAN

Flow chart

Flow Cahart Proses Receiving, Filleting, dan Wahsing

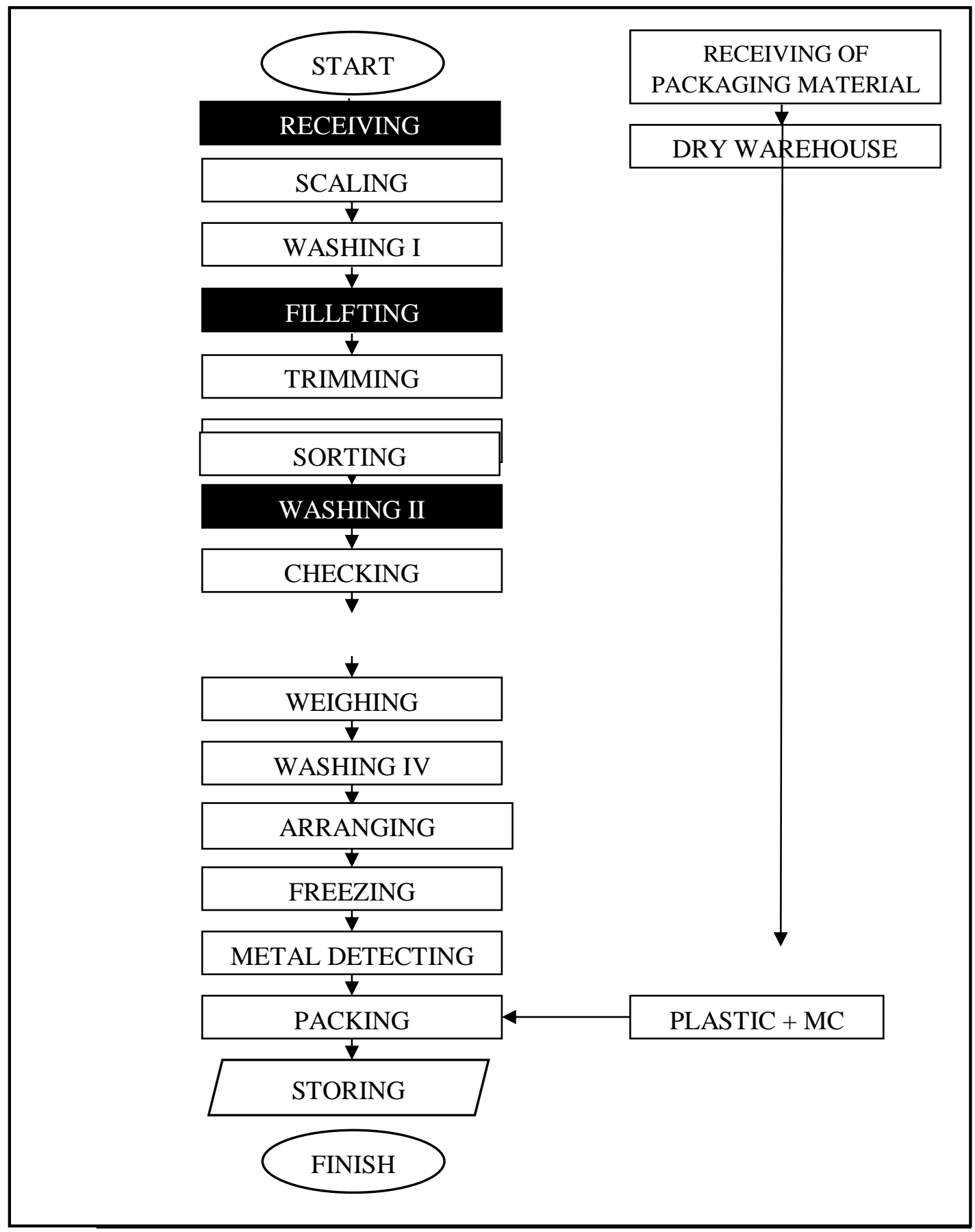

Dari hasil observasi dan watwancara dengan pihak perusahaan, dapat diketahui terdapat tiga jenis kecacatan produk yang terjadi pada proses produksi. Tiga jenis cacat 


\section{Andi Trias Aryanto \\ Tuwanku Aria Auliandri}

tersebut adalah ikan tidak segar, bentuk daging tidak sesuai, dan daging tidak bersih dari duri. Ketiganya berasal dari proses produksi yang dikategorikan receiving, filleting, dan. washing

Check sheets

Check Sheet Kecacatan Produk Fillet Skin On Red Mullet

\begin{tabular}{|l|c|c|c|c|c|c|}
\hline \multirow{2}{*}{$\begin{array}{c}\text { Bulan } \\
\text { (2014) }\end{array}$} & $\begin{array}{c}\text { Jumlah } \\
\text { Produksi } \\
(\mathrm{Kg})\end{array}$ & $\begin{array}{c}\text { Bentuk } \\
\text { daging } \\
\text { tidak sesuai } \\
(\mathrm{Kg})\end{array}$ & $\begin{array}{c}\text { Daging } \\
\text { lembek } \\
(\mathrm{Kg})\end{array}$ & $\begin{array}{c}\text { Daging } \\
\text { tidak } \\
\text { bersih dari } \\
\text { duri (Kg) }\end{array}$ & $\begin{array}{c}\text { Total } \\
\text { Kecacatan } \\
(\mathrm{Kg})\end{array}$ & $\begin{array}{c}\text { Presentase } \\
\text { Keacatan }\end{array}$ \\
\hline Januari & 4045,7 & 10,3 & 6,5 & 1,1 & 17,9 & $0,442445 \%$ \\
\hline Februari & 3165 & 6 & 6,3 & 2,2 & 14,5 & $0,458136 \%$ \\
\hline Maret & 5611,6 & 15,4 & 12,9 & 3,3 & 31,6 & $0,563119 \%$ \\
\hline April & 8078,4 & 14,1 & 11,3 & 1,5 & 26,9 & $0,332987 \%$ \\
\hline Mei & 7821,5 & 7,7 & 10,6 & 3,8 & 22,1 & $0,282554 \%$ \\
\hline Juni & 5188,3 & 12,6 & 2,5 & 1,7 & 16,8 & $0,323805 \%$ \\
\hline Juli & 9724,4 & 19,5 & 7,6 & 1,8 & 28,9 & $0,297191 \%$ \\
\hline Agustus & 9007,2 & 23,8 & 8,7 & 5,2 & 37,7 & $0,418554 \%$ \\
\hline September & 10602,6 & 16,7 & 9,6 & 1,5 & 29,8 & $0,281063 \%$ \\
\hline Oktober & 10211,6 & 33,2 & 10,3 & 2,9 & 46,4 & $0,454385 \%$ \\
\hline November & 12814,8 & 27,4 & 6,8 & 5,3 & 39,5 & $0,308237 \%$ \\
\hline Desember & 9620,7 & 13,5 & 6,3 & 1,6 & 21,4 & $0,222437 \%$ \\
\hline Total & 95891,8 & 200,2 & 99,4 & 31,9 & 333,5 & $0,347788 \%$ \\
\hline
\end{tabular}

Dari data yang diperoleh dapat dilihat bahwa terdapat tiga jenis kecacatan yang terjadi pada produk Fillet Skin On Red Mullet, bentuk daging tidak sesuai, daging lembek, dan daging tidak bersih dari duri. Dari total produksi sebanyak 95.891,8 kg terdapat jenis kecacatan yang paling besar adalah bentuk daging tidak sesuai sebesar 200,2 kg, kemudian dagigng lembek sebesar $99,4 \mathrm{~kg}$, dan yang terakhir daging tidak bersih dari duri sebesar $31,9 \mathrm{~kg}$

Histogram

Dapat dilihat besaran distribusi kecacatan produk yang terjadi tiap bulannya pada Gambar 4.. Histogram ini diambil dari data yang terdapat di check sheet. Dari gambar histogram tersebut dapat diketahui bahwa jumlah kecacatan terbear terjadi pada bualn Oktober sebesar $46,4 \mathrm{~kg}$, dan jumlah kecacatan paling kecil terjadi pada bulan Februari sebesar 14,5 kg. Dalam kurun waktu satun tahun terjadi fluktuasi jumlah kecacatan produk. 
Dapat dilihat dalam enam bulan awal jumlah kecacatannya cenderung sedikit, dibandingkan dengan jumlah kecacatan pada enam bulan terakhir.

\section{Histogram Jenis Kecacatan Produk Fillet Skin On Red Mullet}

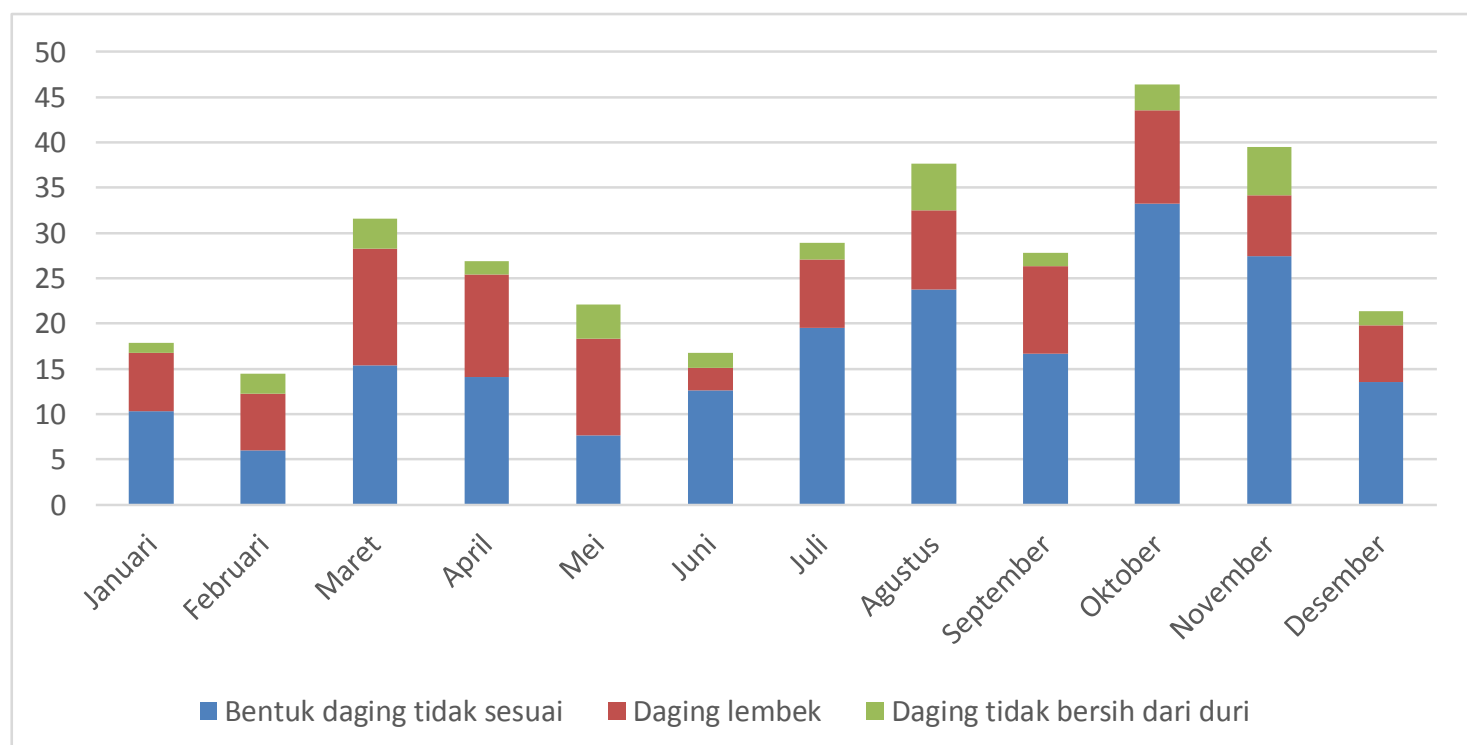

Diagram pareto

Pada gambar di atas, dapat diketahui penyebab kecacatan paling tinggi berasal dari manusia, yaitu sebesar $54 \%$ dari seluruh kategori penyebab kecacatan yang ada. Sedangkan peralatan menempati urutan kedua penyebab kecacatan yang terjadi yaitu sebesar $22 \%$. Komdisi suhu menempati posisi setalahnya dengan besar presentase $12 \%$. Setealah itu ada material yang berada diposisi keempat dengan presentase $9 \%$. Dan yang terakhir adalah metode yang berada di urutan kelima dengan besar presentase $3 \%$.

Cause and Effect Diagram

Untuk mempermudah menidentifikasi penyebab kecacatan suatu produk dapat menggunakan cause and effect diagram. Diagram dengan nama lain diagram tulang ikan (fishbone diagram) adalah sebuah teknik skematik yang digunakan untuk mengetahui hubungan sebab akibat. Dengan menggunakan cause and effect diagram dapat diketahui akar penyebab terjadinya masalah kecacatan produk yang dikelompokkan menjadi lima ketegori, yaitu mesin, manusia, material, metode, dan lingkungan. Analisis cause and effect diagram ini diperoleh dari hasil wawancara dengan pihak perusahaan dan dokumnetasi penulis.

Penyebab terjadinya kecacatan bentuk daging tidak sesuai dapat dijelaskan sebagai berikut. Mata pisau yang digunakan terus menerus akan menjadi tumpul, dan tidak dapat memotong daging dengan sempurna. Jam kerja yang delapan jam dengan kegiatan yang hanya terbatas pada pemotongan daging saja membuat konsentrasi para karyawan menurun. Ini sering terjadi pada tenaga kerja yang baru direkrut, karena belum terbiasa dan tangannya masih lambat. Peralatan yang digunakan karyawan dalam pemotongan kurang 


\section{Andi Trias Aryanto \\ Tuwanku Aria Auliandri}

mendapatakan perawatan. Kondisi ikan sangat berpengaruh terhadap proses filleting karena daging menjadi lembek dan susah untuk dipotong.

Penyebab terjadinya kecacatan produk daging lembek dapat dijelaskan sebagai berikut. Termometer yang rusak dapat berakibat kurang akuratnya pengukuran air dalam box dan suhu ikan. Kurangnya pengetahuan karyawan terhadap kondisi ikan yang baik atau buruk, dan juga kurangnya ketrampilan karyawan terhadap penggunaan alat. Suhu air dalam box dan suhu ikan dapat dipengaruhi oleh kondisi cuaca yang ada pada saat pengirima. Metode kontrol untuk mendeteksi daging lembek adalah dengan menggunakan termometer yang sesuai dengan GMP (Good Manufacturing Practice) yang ada pada perusahaan.

Penyebab terjadinya kecacatan produk daging tidak bersih dari duri dapat dijelaskan sebagai berikut. Mesin digunakan dengan intensitas yang tinggi kurang lebih selama 8 jam penggunaan. Ketrampilan karyawan mempengaruhi kebersihan dari daging, bila tidak biasa atau terbilang baru maka akan menemiukan kesulitan dan terjadi kecacatan. Dengan suhu air yang dingin $\left(<5^{\circ} \mathrm{C}\right)$ daging tidak akan lembek, sehingga memudahkan dalam proses pencucian

Usulan Perbaiakan dengan FMEA

Pada tabel FMEA, telah dijelasakan tentang perhitungan nilai RPN (Risk Priority Number) dengan mengalikan nilai Severity, Occurence, dan Detection. Berdasarkan hasil perhitungan tersebut, dapat diketahui bahwa penyebab kecacatan yang menjadi prioritas utama untuk dilakukan penanganan adalah kategori manusia hal ini ditunjukakan dari nilai RPN yang paling tinggi yaitu 240. Dengan niali yang tinggi ini berarti banyak kecacatan produk yang berasal dari kesalahan pada katogori manusia. Kemudian, penyebab kecacatan yang menempati urutan kedua adalah kategori peralatan dengan nilai RPN sebesar 124. Di urutan ketiga ada kategori kondisi suhu dengan nilai total RPN sebesar 90. Metode menempati urutan keempat dengan nilai total RPN 54. Dan yang menjadi prioritas penanganan terakhir adalah material dengan nilai RPN sebesar 48. 
Failure Modes and Effects Analaysis Kecacatan Daging tidak Bersih dari Duri

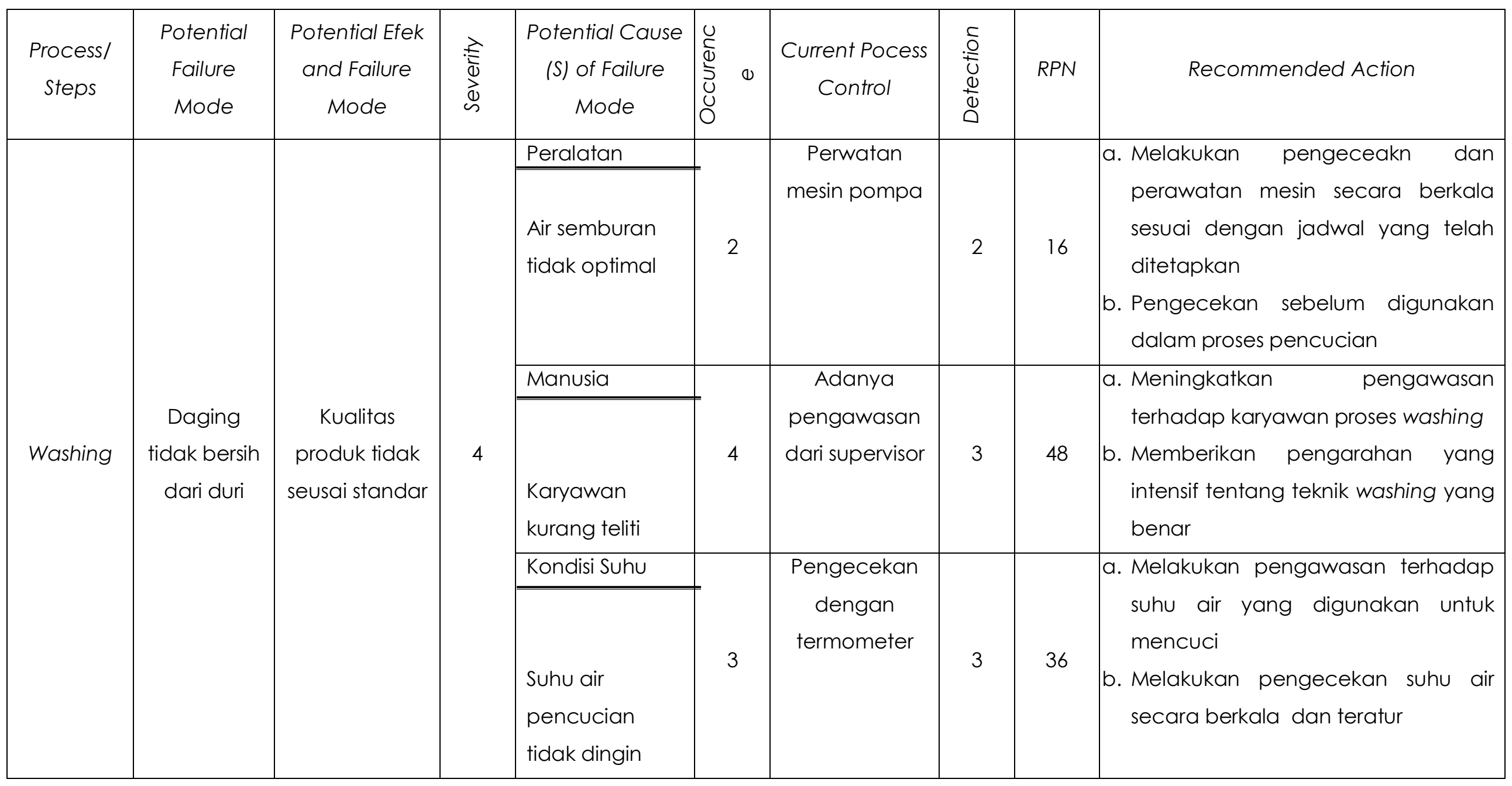




\section{SIMPULAN}

Setelah dilakukan observasi dan analisi terhadap proses produksi Fillet Skin On Red Mullet, terdapat tiga proses produksi yang rentan terjadinya kesalahan dalam produksi yang dapat berakibat kecacatan produk. Tiga proses produksi tersebut adalah receiving, filleting, dan washing, ketiga proses tersebut mempunyai pengaruh yang signifikan terhadap hasil barang jadi. Kecacatan yang terjadi pada tahapan tersebut meliputi bentuk daging salah, ikan tidak segar, dan daging tidak bersih dari duri. Berdasarkan hasil dari analisis cause and effect diagram menunjukkan bahwa kecacatan bentuk daging salah disebabkan oleh pisau tidak memotong sempurna, karyawan kurang terampil, karyawan tidak teliti, dan ikan yang tidak segar. Selanjutnya kecaactan ikan tidak segar disebabkan termometer rusak, sortir kurang optimal, suhu dalam box tinggi, dan metode kontrol kurang baik. Danyang terakhir penyebab kecacatan daging tidak bersih dari duri adalah mesin kurang optimal, suhu air untuk mencuci tidak terjaga, dan kinerja karyawan kurang optimal. Dengan diagram pareto dapat, diketahui penyebab kecacatan produk Fillet Skin On Red Mullet paling banyak adalah kategori manusia sebesar $54 \%$. Untuk sterusnya adalah kategori peralatan sebesar $22 \%$, kondisi suhu sebesar $12 \%$, material sebesar $9 \%$, dan maetode sebesar $3 \%$. Dengan begitu dapat diketahui urutan dari setiap kategori yang menjadi penyebab kecacatan produk.

Dari hasil tabel FMEA dapat diketahui prioritas tindakan perbaikan dimulai dari kategori manusia, peralatan, kondisi suhu, material, dan metode. Untuk kategori manusia rancangan perbaikan dapat dilakukan dengan menambah jumlah supervisor untuk kegiatan proses yang rawan terjadinya kesalahan, melakukan pelatihan terhadap karyawan yang baru direkrut, dan menanamkan pentingnya menjaga kualitas pada setiap orang yang terlibat dalam kegiatan produksi. Yang kedua kategori peralatan rancangan perbaikan yang dilakukan adalah pengecekan dan perawatan secara berkala sebelum dan sesudah penggunakan alat untuk produksi, hal ini juga dapat menghindari kerusakan yang lebih besar dan dapat menyebabkan biaya perbaikan yang tinggi atau biaya penggantian mesin. Selanjutnya kategori kondisi suhu melakukan perbaikan dengan cara mengecek suhu air untuk pencucian, serta memperketat pengawasan terhadap kondisi dari box pada saat penerimaan. Untuk penyebab kecacatan kategori material melakukan penjagaan kesegaran bahan baku ikan pada tahap sebelumnya, memperketat sortir pada saat penerimaan, dan memilih supplier yang mampu menyedaiakan bahan baku ikan yang memenuhi standar perusahaan. Terakhir adalah metode untuk tidakan yang perlu dilakukan guna meminimalkan kecaactan adalah dengan cara menempel GMP pada setiap tempat berlangsungnya proses produksi, sehingga karyawan dapat mengetahui tata cara. yang benar. 


\section{DAFTAR PUSTAKA}

Aryanto, Andi Trias dan Tuwanku Aria Auliandri, 2015. Analisis Kecacatan Produk Fillet Skin On Red Mullet Dengan The Basic Seven Tools Of Quality dan Usulan Perbaikannya Menggunakan Metode Failure Modes and Effect Analysis (FMEA) Pada PT. HOLI MINA JAYA, Program Studi S1 Manajemen Fakultas Ekonomi dan Bisnis Universitas Airlangga, 133.

Besterfield. Dale H. 1994. Qualiti Control. Fourth Edition. USA: Prentice Hall.

David, R. Bamford and Richard W. Greatbanks. The Use of Quality Management Tools and Techniques: A Study of Application in Everyday Situations. International Journal of Quality \& Reliability Management.

Evans, James R. and William M. Lindsay. 2008. The Management and Control of Quality. Seventh Edition. Canada: Thomas South-Western.Vol. 22. No. 4. Emerald Group Publishing Limited.

Ellitan, L., Anantan, L., 2008. Manajemen Strategi Operasi : Teori dan Riset di Indonesia. Bandung: Alfabeta.

Feigenbaum, A.V. 1991. Total Quality Control. New York: McGraw Hill Press.

Foster, Thomas S. 2007. Managing Quality. Thrid Edition. USA: Pearson Prentice Hall.

Heizer, Jay and Barry Render. 2006. Operation Management (Mananjemen Operasi). Edisi Ketujuh. Terjemahan oleh: Dwianoegrahwati Setyoningsih dan Indra Almahdya. Jakarta: Salemba Empat.

Ipotnews.com.(https://www.ipotnews.com/index.php?.jdl=Potensi_Kontribusi_Sektor_Perikana n_Kelautan_Masih_Sangat_Besar, diakses pada 21 Januari 2015).

Juran, J.M. 1989. Juran on Leadership for Quality. New York: The Free Press.

Krajewski, Lee J. and Larry Ritzman. 2005. Operations Management Processes and Valve Chains. Seventh Edition. New Jersey: Prentice Hall.

Kukulies, Jan, et al. 2014. Digital Planning of Harmonised Quality Testing Activities Throught the Product Life Cycle. 8th International Conference on Digital Enterprise Technology.

Nasution, Arman Hakim. 2006. Manajemen Industri. Yogyakarta: Andi.

Paciarotti, Claudia, et al. 2013. A Revised FMEA Application to the Quality Control Management. International Journal of Quality \& Reliability Management. Vol. 31. No. 7.

Pande, Peter S, et al. 2002. The Six Sigma Way (Bagaimana GE. Motorola, dan perusahaan Terkenal Lainnya Mengasah Kinerja Mereka). Tejemahan oleh: Dwi Parabantini. Yogyakarta: Andi.

Perdani, Reni Anggun. 2012. Usulan Perbaikan Kualitas Produk Snack Mie Hancur Dengan Menggunakan Metode FMEA Di PT Siantar Top, Tbk. Skripsi tidak diterbitkan. Fakultas Ekonomi dan Bisnis Universitas Airlangga. 


\section{Andi Trias Aryanto \\ Tuwanku Aria Auliandri}

PT. Holi Mina Jaya. (http://holiminajaya.com/, diakses pada 21 Januari 2015).

Ramadhani, Aryo Himanda. 2013. Rancangan Perbaikan Kualitas Produk Bantalan Rel Dengan Menggunakan Metode FMEA (Failure Modes and Effect Ananlysis) Pada PT. Wijaya Karya Beton. Skripsi tidak diterbitkan. Fakultas Ekonomi dan Bisnis Universitas Airlangga.

Sokovic, Mirko, et al. 2009. Basic Quality Tools in Continuous Improvement Process. Journal of Mechanical Engineering. Vol. 55. No. 5.

Sugiyono. 2009. Metode Penelitian Bisnis. Bandung: Alfabeta.

Suliyanto. 2006. Metode Riset Bisnis. Yogyakarta: Andi.

Tsani, Retha. 2011. Evaluasi Kecacatan Cangkang Kapsul Lunak Vitamin A 200.000 IU Dengan Analisis The Basic Seven Tools of Quality Dan Usulan Perbaikannya Menggunkan Metode FMEA Di PT. Kimia Farma Tbk. Plant Watudako. Skripsi tidak diterbitkan. Fakultas Ekonomi dan Bisnis Universitas Airlangga.

Vinodh, Sekar and D. Santhosh. 2012. Application of FMEA to An Automotive Leaf Spring Manufacture Organization. The TQM Journal. Vol. 24. No. 3. Emerald Group Publishing Limited.

Wirartha, I Made. 2006. Metodologi Penelitian Sosial Ekonomi. Yogyakarta: Andi.

Xiao, Ningcong, et al. 2011. Multi Failure Modes Analysis and Weighted Risk Priority Number Evaluation in FMEA. Engineering Failure Analysis. Vol. 18. 
Jurnal Manajemen Teori dan Terapan

Tahun 8. No. 1, April 2015 